\title{
MATERNAL PLASMA C-REACTIVE PROTEIN: A PREDICTIVE TOOL FOR PRETERM DELIVERY
}

\author{
Asima Afzal1, Samina Ashraf², Mohd. Ashraf 3 \\ ${ }^{1}$ Senior Resident, Department of Obstetrics and Gynaecology, Government Medical College, Srinagar. \\ ${ }^{2}$ Senior Resident, Department of Obstetrics and Gynaecology, Government Medical College, Srinagar. \\ 3Senior Resident, Department of Obstetrics and Gynaecology, Government Medical College, Srinagar.
}

\section{ABSTRACT}

\section{BACKGROUND}

C-reactive protein (CRP) is a sensitive marker of systemic inflammation and maternal plasma concentrations of C-reactive protein have been studied as an aid in diagnosing subclinical infection in pregnant women who experience preterm labour and premature rupture of membranes.

Objectives- To study the association of plasma C-reactive protein levels in early pregnancy with subsequent preterm delivery.

\section{MATERIALS AND METHODS}

This study was carried out in the Department of obstetrics and gynaecology, Lalla-Ded hospital, Srinagar Kashmir from July 2008 to November 2010. A prospective nested case-control approach was used, in which cases were participants who experienced preterm delivery and controls were those women who delivered at 37 weeks or more. 200 pregnant women with singleton pregnancy were recruited for study and were followed till delivery. Maternal plasma C-reactive protein levels were measured in early pregnancy ( $<22$ weeks of gestation) and were correlated with the time of delivery (preterm/term). The characteristics of cases and controls were compared by using descriptive statistics. Comparative evaluation was done by using Chi-Square test and Odds ratio. All $p$ values of $<0.05$ were regarded as significant. Conditional logistic regression analysis was performed to evaluate the risk of preterm delivery.

\section{RESULTS}

We found statistically significant differences in the C-reactive protein levels measured in early pregnancy between the women who delivered preterm and those delivering at term. Plasma CRP levels were higher in cases than in controls. Mean CRP level was $5.2 \pm 2.9 \mathrm{mg} / \mathrm{L}$ in cases and $2.4 \pm 1.2 \mathrm{mg} / \mathrm{L}$ in controls. Median CRP concentration was also higher in cases ( $4.8 \mathrm{mg} / \mathrm{L})$ than in controls $(2.0 \mathrm{mg} / \mathrm{L})$. The sensitivity, specificity, PPV and NPV of CRP in predicting preterm delivery were found to be $61.0 \%, 88.7 \%, 58.1 \%$ and $89.8 \%$ respectively, at a cut-off value of $3.6 \mathrm{mg} / \mathrm{L}$.

\section{CONCLUSION}

Elevated CRP level in early pregnancy is associated with preterm delivery. Therefore, measurement of plasma CRP level in early pregnancy can serve as a predictive tool for subsequent preterm delivery.

\section{KEYWORDS}

C-reactive Protein, Preterm Delivery, Pregnancy.

HOW TO CITE THIS ARTICLE: Afzal A, Ashraf S, Ashraf M. Maternal plasma c-reactive protein: A predictive tool for preterm delivery. J. Evolution Med. Dent. Sci. 2017;6(5):369-374, DOI: 10.14260/Jemds/2017/84

\section{BACKGROUND \\ Preterm birth, defined as birth before 37 weeks gestation, is an important cause of neonatal and infant morbidity and mortality. \\ Overall incidence of preterm labour is reported to be 6- $15 \%$.(1) Nearly $50-60 \%$ preterm births occur following spontaneous labour, $30 \%$ due to preterm premature rupture of membranes and the rest are iatrogenic terminations for maternal or foetal benefit. Four different pathways have been identified that can result in preterm birth and have considerable evidences: precocious foetal endocrine activation, uterine over distension, decidual bleeding and intrauterine inflammation/infection.}

Financial or Other, Competing Interest: None.

Submission 11-12-2016, Peer Review 04-01-2017,

Acceptance 10-01-2017, Published 16-01-2017.

Corresponding Author:

Dr. Asima Afzal,

Senior Resident

Postgraduate,

Department of Obstetrics and Gynaecology,

Government Medical College, Srinagar.

E-mail: drasmamantoo@gmail.com

DOI: $10.14260 /$ jemds $/ 2017 / 84$
Activation of one or more of these pathways may happen gradually over weeks, even months.(2)

Maternal plasma concentrations of C-reactive protein have been studied as an aid in diagnosing subclinical infection in pregnant women who experience preterm labour and premature rupture of membranes. $(3,4)$

C-reactive protein (CRP) is a sensitive marker of systemic inflammation and is primarily synthesised in hepatocytes in response to infection and tissue injury.(5) It plays many roles in the inflammatory process. It binds to the surface of pathogens and opsonises them for uptake by phagocytes. Creactive protein can also activate the classical complement cascade by binding to complement protein C1q.(6) Another proinflammatory function of C-reactive protein includes the induction of cytokines and tissue factor in monocytes.(7) However, its main function is anti-inflammatory by decreasing neutrophil migration to the site of inflammation, preventing adhesion of neutrophils to endothelial cells(8) and affecting clearance of nuclear antigens released from apoptotic or necrotic cells. ${ }^{(9)}$

The median normal concentration of C-reactive protein is $0.8 \mathrm{mg} / \mathrm{L}$, with $90 \%$ of apparently healthy individuals having a value less than $3 \mathrm{mg} / \mathrm{L}$ and $99 \%$ less than $12 \mathrm{mg} / \mathrm{L}$. Higher 
values are abnormal and indicate the presence of organic disease.(10)

The present study was undertaken to evaluate the usefulness of early pregnancy plasma C-reactive protein in the prediction of preterm delivery.

\section{MATERIALS AND METHODS}

This study was carried out in the Department of Obstetrics and Gynaecology, Lalla-Ded Hospital, Government Medical College, Srinagar from year 2008-2010. A total of 200 pregnant women were recruited for study and were followed till delivery (preterm/term). Maternal plasma C-reactive protein levels were measured in early pregnancy $(<22$ weeks gestation) and were correlated with the time of delivery (preterm/term).

The research protocol was approved by the institutional ethical committee. All participants received a detailed explanation of the study before providing their signed consent.

\section{Type of Study}

Prospective nested cohort study.

\section{Data Collection}

At the initial prenatal visit, plasma sample was drawn from each participant, collected in ethylenediamine-tetraacetic acid, refrigerated for several hours and then transported to the laboratory where it was centrifuged and frozen until the time of analysis. Gestational age at blood sampling was 6-22 weeks.

\section{Case-Control Selection}

In this analysis, a prospective nested case-control approach was used, in which cases were participants who experienced preterm delivery ( $<37$ weeks gestation). Controls were those women who delivered at gestational age of 37 weeks or more. CRP levels were done in the Biochemistry Laboratory, Government Medical College, Srinagar, with a validated highsensitivity immunoturbidimetric assay on the Siemens Fully Automated Biochemistry Analyser.

\section{Statistical Analysis}

The baseline and delivery characteristics of cases and controls were compared by using descriptive statistics. Comparative evaluation was done by using Chi-Square test and Odds ratio. All p-values of $<0.05$ were regarded as significant.

\section{RESULTS}

A prospective study was carried out on 200 women with singleton pregnancy. Women who delivered before 37 weeks of gestation (preterm) constituted the cases and who delivered at term constituted the controls.

Majority of the study subjects were in the age group of 2034 years. Mean age was found to be $28.6 \pm 6.7$ years and $28.9 \pm 5.3$ years among cases and controls respectively. There was no statistical significance of age between the cases and controls. Mean BMI was found to be slightly higher among controls $\left(23.9 \pm 3.3 \mathrm{~kg} / \mathrm{m}^{2}\right)$ as compared to the cases $(23.5 \pm 3.4$ $\mathrm{kg} / \mathrm{m}^{2}$ ). The difference in BMI between cases and controls was found to be statistically insignificant (Table 1).

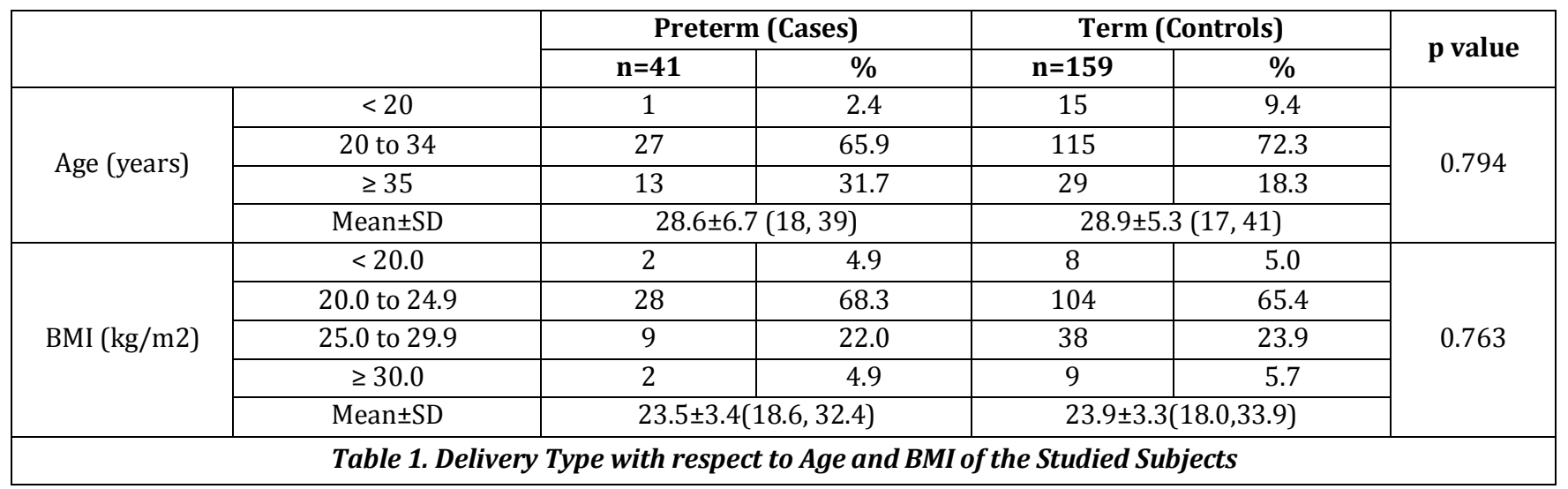

BMI=Body Mass Index, P value $<0.05$ statistically significant.

As depicted in the Table 2, we found a statistically significant risk of preterm delivery in women with a gravidity of greater than three. With regard to history of previous abortion(s), there was statistically significant difference between the cases and controls. In case of multigravidas ( $\mathrm{n}=121)$, mean interpregnancy interval was found to be shorter $(12.3 \pm 8.0$ months $)$ in cases as compared to the controls $(14.0 \pm 5.8$ months). Pregnant women with a short inter pregnancy interval had a statistically significant risk of preterm delivery. Among multigravida subjects who delivered preterm (cases), 30.4\% had a history of previous preterm delivery whereas in the case of multigravida subjects who delivered at term (controls), only $4.1 \%$ had such history. A statistically significant risk of recurrent preterm delivery in the next pregnancy was found in our study. In case of multigravidas, no history of previous caesarean section was seen in $82.6 \%$ and $87.8 \%$ among cases and controls respectively, whereas a history of previous caesarean section was seen in $17.4 \%$ and $12.2 \%$ among cases and controls respectively. The difference was found to be statistically insignificant. 


\begin{tabular}{|c|c|c|c|c|c|c|}
\hline & & \multicolumn{2}{|c|}{ Preterm (Cases) } & \multicolumn{2}{|c|}{ Term (Controls) } & \multirow{2}{*}{$p$ value } \\
\hline & & $n=41$ & $\%$ & $n=159$ & $\%$ & \\
\hline \multirow{2}{*}{ Gravidity } & $\leq 3$ & 20 & 48.8 & 125 & 78.6 & 0.000 \\
\hline & $>3$ & 21 & 51.2 & 34 & 21.4 & \\
\hline \multirow{3}{*}{ Abortion(s) } & Nil & 15 & 36.6 & 100 & 62.9 & 0.002 \\
\hline & $1-2$ & 22 & 53.7 & 53 & 33.3 & \\
\hline & $\geq 3$ & 4 & 9.7 & 6 & 3.8 & \\
\hline \multirow{3}{*}{$\begin{array}{l}\text { Interpregnancy Interval } \\
\text { (months)(in multigravidas) }\end{array}$} & $<6$ months & 7 & 30.4 & 7 & 7.1 & 0.002 \\
\hline & $\geq 6$ months & 16 & 69.6 & 91 & 92.9 & \\
\hline & Mean \pm SD & \multicolumn{2}{|c|}{$12.3 \pm 8.0(4,36)$} & \multicolumn{2}{|c|}{$14.0 \pm 5.8(4,32)$} & \\
\hline \multirow{2}{*}{$\begin{array}{l}\text { H/O Previous Preterm Delivery } \\
\text { (in multigravidas) }\end{array}$} & Yes & 7 & 30.4 & 4 & 4.1 & 0.000 \\
\hline & No & 16 & 69.6 & 94 & 95.9 & \\
\hline \multirow{2}{*}{$\begin{array}{c}\text { H/O Previous LSCS } \\
\text { (in multigravidas) }\end{array}$} & No & 19 & 82.6 & 86 & 87.8 & 0.683 \\
\hline & Yes & 4 & 17.4 & 12 & 12.2 & \\
\hline
\end{tabular}

LSCS=Lower segment caesarean section, $\mathrm{P}$ value $<0.05$ statistically significant.

As depicted in the Table 3, mean plasma CRP levels were high $(5.2 \pm 2.9 \mathrm{mg} / \mathrm{L})$ in the subjects who delivered preterm as compared to the CRP levels in subjects who delivered at term $(2.4 \pm 1.2 \mathrm{mg} / \mathrm{L}$ ). Median CRP levels were also found to be higher (4.8 $\mathrm{mg} / \mathrm{L})$ among cases as compared to controls $(2.0 \mathrm{mg} / \mathrm{L})$. We found a statistically significant risk of preterm delivery in women with raised CRP levels.

\begin{tabular}{|c|c|c|c|}
\hline Plasma CRP (mg/L) & Preterm (cases) & Term (controls) & p value \\
\hline Mean \pm SD & $5.2 \pm 2.9(1.4,14.2)$ & $2.4 \pm 1.2(0.8,8.2)$ & 0.000 \\
\hline Median(IQR) & $4.8(2.6,6.9)$ & $2.0(1.6,2.8)$ & 0.000 \\
\hline \multicolumn{4}{|l}{ Table 3. Delivery Type with respect to CRP Levels of the Studied Subjects } \\
\hline
\end{tabular}

$\mathrm{SD}=$ Standard deviation, IQR= Inter Quartile Range, $\mathrm{P}$ value $<0.05$ statistically significant.

As shown in the Table 4, among subjects who delivered preterm, mean CRP levels were higher in those who delivered before 34 weeks of gestation $(7.3 \mathrm{mg} / \mathrm{L})$ than the subjects who delivered between 34-36 weeks of gestation ( $4.1 \mathrm{mg} / \mathrm{L})$. The difference was again found to be statistically significant. Mean CRP level in multigravidas with previous history of preterm delivery was found to be higher $(5.4 \mathrm{mg} / \mathrm{L})$ as compared to the multigravidas with no such history $(2.7 \mathrm{mg} / \mathrm{L})$. The difference was found to be statistically significant.

\begin{tabular}{|c|c|c|c|c|c|c|}
\hline & & Min & Max & Mean & SD & p value \\
\hline \multirow{2}{*}{ Delivery Type } & Preterm & 1.4 & 14.2 & 5.2 & 2.9 & \multirow{2}{*}{0.000} \\
\hline & Term & 0.8 & 10.2 & 2.4 & 1.2 & \\
\hline \multirow{3}{*}{ Gestational Age (weeks) } & $<34$ & 2.4 & 14.2 & 7.3 & 2.8 & \multirow{3}{*}{0.000} \\
\hline & $34-36$ & 1.4 & 10.4 & 4.1 & 2.3 & \\
\hline & $\geq 37$ & 0.8 & 10.2 & 2.4 & 1.2 & \\
\hline \multirow{2}{*}{ H/O Previous Preterm Delivery } & Yes & 2.4 & 10.2 & 5.4 & 2.8 & \multirow[t]{2}{*}{0.000} \\
\hline & No & 0.8 & 10.4 & 2.7 & 1.9 & \\
\hline \multirow{4}{*}{ BMI $\left(\mathrm{kg} / \mathrm{m}^{2}\right)$} & $<20.0$ & 1.4 & 6.2 & 3.0 & 1.5 & \multirow{4}{*}{0.915} \\
\hline & $20.0-24.9$ & 1.2 & 10.4 & 2.9 & 2.0 & \\
\hline & $25.0-29.9$ & 1.2 & 14.2 & 3.0 & 2.3 & \\
\hline & $\geq 30.0$ & 0.8 & 10.2 & 3.3 & 2.8 & \\
\hline
\end{tabular}

Table 4. Plasma CRP Levels (mg/L) in the Studied Subjects

BMI= Body Mass Index, $\mathrm{P}$ value $<0.05$ statistically significant.

As depicted in the Table 5, if cut-off value for plasma CRP is taken as $1.6 \mathrm{mg} / \mathrm{L}$ for preterm delivery, the sensitivity is $95.1 \%$ and specificity is $20.8 \%$, with Odds ratio(95\% CI $)=5.1(1.2-22.2)$. If we take cut-off value as $2.2 \mathrm{mg} / \mathrm{L}$, the sensitivity and specificity are $87.8 \%$ and $51.6 \%$ respectively, with Odds ratio $(95 \% \mathrm{CI})=7.7(2.9-20.5)$. Similarly, for CRP level of $3.6 \mathrm{mg} / \mathrm{L}$ as cut-off, the sensitivity, specificity and Odds ratio(95\%CI) are $61.0 \%, 88.7 \%$ and $12.2(5.5-27.1)$ respectively.

\begin{tabular}{|c|c|c|c|c|c|c|}
\hline \multirow{2}{*}{\multicolumn{2}{|c|}{ Sensitivity/Specificity }} & \multicolumn{2}{|c|}{ Preterm } & \multicolumn{2}{|c|}{ Term } & \multirow{2}{*}{ OR (95 \% CI) } \\
\hline & & $\mathbf{n}$ & $\%$ & $\mathbf{n}$ & $\%$ & \\
\hline \multirow{2}{*}{ Ist Quartile Plasma CRP (mg/L) } & $\geq 1.6$ & 39 & 95.1 & 126 & 79.2 & \multirow{2}{*}{$5.1(1.2$ to 22.2$)$} \\
\hline & $<1.6$ & 2 & 4.9 & 33 & 20.8 & \\
\hline \multirow{2}{*}{$2^{\text {nd }}$ Quartile Plasma CRP (mg/L) } & $\geq 2.2$ & 36 & 87.8 & 77 & 48.4 & \multirow{2}{*}{$7.7(2.9$ to 20.5$)$} \\
\hline & $<2.2$ & 5 & 12.2 & 82 & 51.6 & \\
\hline \multirow{2}{*}{$3^{\text {rd }}$ Quartile Plasma CRP (mg/L) } & $\geq 3.6$ & 25 & 61.0 & 18 & 11.3 & \multirow{2}{*}{$12.2(5.5$ to 27.1$)$} \\
\hline & $<3.6$ & 16 & 39.0 & 141 & 88.7 & \\
\hline $\begin{array}{r}\text { Table } 5 \\
\text { delivery accord } \\
\end{array}$ & $\begin{array}{l}y, \text { Spe } \\
\text { ternal }\end{array}$ & sma & $\begin{array}{l}\text { ratio } \\
\text { Levels }\end{array}$ & $\begin{array}{l}95 \% 0 \\
\text { sured }\end{array}$ & $\begin{array}{l}\text { reter } \\
\text { arlyp }\end{array}$ & \\
\hline
\end{tabular}


As depicted in the Table 6, if cut-off value for plasma CRP is taken as $1.6 \mathrm{mg} / \mathrm{L}$ for preterm delivery, the PPV is $23.6 \%$ and NPV is $94.3 \%$, with Odds ratio $(95 \% \mathrm{CI})=5.1(1.2-22.2)$. If we take cut-off value as $2.2 \mathrm{mg} / \mathrm{L}$, the PPV and NPV are $31.9 \%$ and $94.3 \%$ respectively, with Odds ratio(95\%CI) $=7.7(2.9-20.5)$. Similarly, for CRP level of $3.6 \mathrm{mg} / \mathrm{L}$ as cut-off, the PPV, NPV and Odds ratio(95\% $\mathrm{CI})$ are $58.1 \%, 89.8 \%$ and $12.2(5.5-27.1)$ respectively.

\begin{tabular}{|c|c|c|c|c|c|c|}
\hline \multirow{2}{*}{\multicolumn{2}{|c|}{ PPV/NPV }} & \multicolumn{2}{|c|}{ Preterm } & \multicolumn{2}{|c|}{ Term } & \multirow{2}{*}{ OR $(95 \% \mathrm{CI})$} \\
\hline & & $\mathbf{n}$ & $\%$ & $\mathbf{n}$ & $\%$ & \\
\hline \multirow{2}{*}{ Ist Quartile_Plasma CRP (mg/L) } & $\geq 1.6$ & 39 & 23.6 & 126 & 76.4 & \multirow{2}{*}{$5.1(1.2$ to 22.2$)$} \\
\hline & $<1.6$ & 2 & 5.7 & 33 & 94.3 & \\
\hline \multirow{2}{*}{$2^{\text {nd }}$ Quartile_Plasma CRP (mg/L) } & $\geq 2.2$ & 36 & 31.9 & 77 & 68.1 & \multirow{2}{*}{7.7 (2.9 to 20.5$)$} \\
\hline & $<2.2$ & 5 & 5.7 & 82 & 94.3 & \\
\hline \multirow{2}{*}{$3^{\text {rd }}$ Quartile_Plasma CRP (mg/L) } & $\geq 3.6$ & 25 & 58.1 & 18 & 41.9 & \multirow{2}{*}{$12.2(5.5$ to 27.1$)$} \\
\hline & $<3.6$ & 16 & 10.2 & 141 & 89.8 & \\
\hline $\begin{array}{r}\text { Table 6: PP } \\
\text { to } M a t\end{array}$ & $\begin{array}{l}\text { dds ro } \\
\text { asma }\end{array}$ & $\begin{array}{l}\text { and } \\
\text { Leve }\end{array}$ & $\begin{array}{l}\text { CI of } \\
\text { easur }\end{array}$ & $\begin{array}{l}\text { erma } \\
\text { earl }\end{array}$ & $\begin{array}{l}\text { eryacc } \\
\text { egnanc }\end{array}$ & \\
\hline
\end{tabular}

\section{DISCUSSION}

Preterm delivery, defined as delivery prior to the completion of 37 weeks gestation, is an important determinant of neonatal and infant morbidity and mortality. Therefore, prediction and prevention of preterm delivery is very important for improvement in neonatal outcome.

Today, several clinical and biochemical markers like Creactive protein, fetal fibronectin, interleukin-8, alphafetoprotein, granulocyte elastase, insulin-like growth factor binding protein-1, measurement of cervical length and detection of cervical funnelling etc have been reported to be associated with preterm delivery. Among these, elevated levels of maternal plasma C-reactive protein are significantly correlated with an increased risk of preterm delivery. ${ }^{(11,12)}$

The published results of various authors like Foulon $\mathrm{W}$ et al,(11) Gitte B et al,(12) Reron A et al,(13) Waranuch P et al,(14) Vitool L et al,(15) Grgic G et al,(16) Riboni $\mathrm{F}$ et al(17) and more recently Shabdika Kulshreshtha,(18) all point towards the usefulness of maternal plasma $\mathrm{C}$-reactive protein in the prediction of preterm delivery. In our present study, we also achieved similar encouraging results with regard to the effectiveness of maternal plasma C-reactive protein levels in predicting preterm delivery.

In the present study, majority of subjects were in the age group of 20-34 years among both cases and controls (65.9\% among cases and $72.3 \%$ among controls). Mean age in the cases was $28.6 \pm 6.7$ years while as in controls it was $28.9 \pm 5.3$ years. There was no significant statistical difference in age between the cases and controls. Our study was comparable to other studies. Vitool L et al(15) in their study of 1769 patients, found that majority of patients were in the age group of 20-34 years (65\% among cases and $70.6 \%$ among controls). Mean age in cases was $32.2 \pm 0.46$ years and in controls was $32.1 \pm 0.11$ years. The difference in age was statistically insignificant. In the study done by Mirzaie $\mathrm{F}$ et al,(19) mean age in patients delivering preterm was 26.7 years and in patients delivering at term was 26.5 years, and the difference was statistically insignificant. In a similar study done by Fatima $\mathrm{A}$ et $\mathrm{al}^{(20)}$ median age in cases and controls was found to be 27.6 years and 27.7 years respectively. The difference was statistically insignificant.

The study subjects were analysed as per their gravidity. Among the cases $48.8 \%$ had a gravidity of $\leq 3$ whereas among the controls $78.6 \%$ had a gravidity of $\leq 3$. Gravidity of $>3$ was seen in $51.2 \%$ of cases and $21.4 \%$ of controls. The difference in gravidity between the cases and controls was found to be statistically significant. Our study showed a significant risk of preterm delivery in women with gravidity $>3$. No study was available for comparison.

The correlation of previous abortion(s) with subsequent preterm delivery was analysed. In our study, $36.6 \%$ subjects among cases and $62.9 \%$ subjects among controls had no history of previous abortion(s); $53.7 \%$ subjects among cases and $33.3 \%$ among controls had history of $1-2$ abortion(s); and 9.7\% subjects among cases and 3.8\% among controls had history of $\geq 3$ abortions. We found a statistically significant difference between the cases and controls with regard to the history of previous abortion(s). Brown JS et al,(21) Chung-Chin $\mathrm{L}$ et al,(22) Freak-Poli R et al(23) and Gordon CS et al(24) in their study found that preterm delivery was more common among patients with history of $\geq 3$ abortions than those with no history of previous abortion(s), which is consistent with our study.

Out of a total of 200 study subjects, 121 were multigravidas, in whom the relationship between interpregnancy interval and preterm delivery was analysed. In our study $30.4 \%$ cases and $7.1 \%$ controls had an interpregnancy interval of $<6$ months whereas $69.6 \%$ cases and $92.9 \%$ controls had an interpregnancy interval $\geq 6$ months. We found a statistically significant risk of getting preterm delivery when interpregnancy interval was $<6$ months. Our study was comparable to the study done by Fatima A et al,(20) Smith $\mathrm{G}$ et al(25) and Kontantinos $\mathrm{C}$ et al(26) who also studied the relationship of interpregnancy interval with preterm delivery. They concluded that a short interpregnancy interval ( $<6$ months) is an independent risk factor for preterm delivery.

In the present study, $30.4 \%$ multigravidas among cases and $4.1 \%$ multigravidas among controls had a history of previous preterm delivery. We found a statistically significant risk of getting recurrent preterm delivery in the next pregnancy. Our study was comparable to the study done by Gitte B et al(12) who also found a statistically significant difference between the preterm and term delivery patients with regard to the history of previous preterm delivery. In the study done by Esplin_MS, O'Brien_E et al,(25) it was found that history of a spontaneous birth before 34 weeks of gestation is a strong predictor of subsequent spontaneous preterm birth, which is consistent with our study. Mirzaie F et al(19) in their study of 988 patients found that previous history of preterm delivery was more common among the patients delivering preterm than the patients delivering at term. 
In a similar study done by Fatima $\mathrm{A}$ et al(20), previous history of preterm delivery was present in $23 \%$ of cases (patients delivering preterm) and in only $7 \%$ of controls (patients delivering at term). They also found a statistically significant risk of getting recurrent preterm delivery in the successive pregnancies.

In the present study, the plasma CRP levels among the cases and controls were compared. Mean CRP level in cases and controls was found to be $5.2 \pm 2.9 \mathrm{mg} / \mathrm{L}$ and $2.4 \pm 1.2 \mathrm{mg} / \mathrm{L}$ respectively. Median CRP level was found to be $4.8 \mathrm{mg} / \mathrm{L}$ and $2.0 \mathrm{mg} / \mathrm{L}$ in cases and controls respectively. The difference in plasma CRP between cases and controls was found to be statistically significant. Waranuch $P$ et al(14) in their study of 234 patients, found a median CRP level of $3.2 \mathrm{mg} / \mathrm{L}$ and 2.4 $\mathrm{mg} / \mathrm{L}$ in cases and controls respectively. Vitool L et al(15) in their study found a median CRP level of $4.4 \mathrm{mg} / \mathrm{L}$ and 3.9 $\mathrm{mg} / \mathrm{L}$ in cases and controls respectively. In the study done by Gitte B et al,(12) the median CRP levels were found to be 3.8 $\mathrm{mg} / \mathrm{L}$ and $3.2 \mathrm{mg} / \mathrm{L}$ among cases and controls respectively. These studies showed a statistically significant risk of preterm delivery in patients with raised CRP levels, as also revealed by our study.

The correlation of plasma CRP levels with the gestational age at delivery was studied. Mean CRP level was higher in women who delivered before 34 weeks gestation $(7.3 \mathrm{mg} / \mathrm{L})$ than the women who delivered between 34 and less than 37 weeks $(4.1 \mathrm{mg} / \mathrm{L})$ and those who delivered at term (2.4 $\mathrm{mg} / \mathrm{L})$. We found a statistically significant difference in the CRP levels of the subjects who delivered preterm from those who delivered at term. Waranuch $\mathrm{P}$ et al(14) in their study found a median CRP level of $5.0 \mathrm{mg} / \mathrm{L}$ in patients who delivered before 34 weeks gestation, $2.8 \mathrm{mg} / \mathrm{L}$ in the patients who delivered between 34 and less than 37 weeks and 2.4 $\mathrm{mg} / \mathrm{L}$ in those who delivered at term. They found a statistically significant difference in the CRP levels of these three groups of patients, as seen in our study as well.

In our study of 200 pregnant women, we correlated plasma CRP levels with previous history of preterm delivery. The mean CRP in subjects with and without history of previous preterm delivery was found to be $5.4 \mathrm{mg} / \mathrm{L}$ and 2.7 $\mathrm{mg} / \mathrm{L}$ respectively. The difference was statistically significant. Our study was comparable to the study done by Waranuch $P$ et al(14) who found a median CRP in patients with and without history of previous preterm delivery to be $4.8 \mathrm{mg} / \mathrm{L}$ and 2.5 $\mathrm{mg} / \mathrm{L}$ respectively. They concluded that patients with history of previous preterm delivery have higher CRP levels as compared to the patients without such history.

In the present study, sensitivity, specificity, positive predictive value and negative predictive value for different cut-off values of CRP in predicting preterm delivery were calculated. At a cut-off value of $3.6 \mathrm{mg} / \mathrm{L}$ of CRP, the sensitivity, specificity, positive predictive value and negative predictive value were $61.0 \%, 88.7 \%, 58.1 \%$ and $89.8 \%$ respectively. Our results are consistent with the study done by Sorahiro S, Kimiyo T et al.(27) In their study of 119 patients, they found the sensitivity, specificity, positive predictive value and negative predictive value of CRP in prediction of preterm delivery as $50 \%, 85.7 \%, 55.6 \%$ and $82.8 \%$ respectively. In the study done by Mazor M, Kassis A et al,(28) the sensitivity, specificity, positive predictive value and negative predictive value of CRP in predicting preterm delivery due to intra-amniotic infection were found to be
$71.5 \%, 73.2 \%, 31.3 \%$ and $93.8 \%$ respectively. Zou L, Zhang $\mathrm{H}$ et al(30) in their study of 75 patients, found the sensitivity, specificity, positive predictive value and negative predictive value of CRP in predicting preterm delivery due to premature rupture of membranes as $81 \%, 73.5 \%, 65.4 \%$ and $86.2 \%$ respectively.

\section{CONCLUSION}

Based on these observations, it is concluded that elevated plasma C-reactive protein level in early pregnancy is associated with preterm delivery. Therefore, measurement of plasma C-reactive protein level in early pregnancy can serve as a predictive tool for subsequent preterm delivery, as it is a simple, rapid and cost-effective test.

\author{
Abbreviations \\ $\mathrm{BMI}=$ Body Mass Index . \\ $\mathrm{CI}=$ Confidence Interval. \\ $\mathrm{CRP}=\mathrm{C}-$ Reactive Protein . \\ $\mathrm{IQR}=$ Interquartile Range. \\ LSCS = Lower Segment Caesarean Section. \\ NPV = Negative Predictive Value. \\ $\mathrm{OR}=$ Odds Ratio. \\ PPV $=$ Positive Predictive Value.
}

\section{REFERENCES}

[1] Anotayanonth S, Subhedar NV, Neilson JP, et al. Betamimetics for inhibiting preterm labour. Cochrane Database Systemic Reviews 2004;(4):CD004352.

[2] Simhan HN, Caritis SN. Prevention of preterm delivery. New England Journal Medicine 2007;357(5):477-87.

[3] Dodds WG, Iams JD. Maternal C-reactive protein and preterm labor. J Report Med 1987;32(7):527-30.

[4] Yoon BH, Jun JK, Park KH, et al. Serum C-reactive protein, white blood cell count, and amniotic fluid white blood cell count in women with preterm premature rupture of membranes. Obstet Gynecol 1996;88(6):1034-40.

[5] Pepys MB, Baltz ML. Acute phase proteins with special reference to $\mathrm{C}$-reactive protein and related proteins (pentaxins) and serum amyloid A protein. Adv Immunol 1983;34:141-212.

[6] Janeway CA, Travers $P$, Walport $M$, et al. Immunobiology. $5^{\text {th }}$ edn. The immune system in health and disease. New York, NY: Garland Publishing 2001.

[7] Cermak J, Key NS, Bach RR, et al. C-reactive protein induces human peripheral blood monocytes to synthesize tissue factor. Blood 1993;82(2):513-20.

[8] Ahmed N, Thorley R, Xia D, et al. Transgenic mice expressing rabbit C-reactive protein exhibit diminished chemotactic factor-induced alveolitis. Am J Respir Crit Care Med 1996;153(3):1141-7.

[9] Burlingame RW, Volzer MA, Harris J, et al. The effect of acute phase proteins on clearance of chromatin from the circulation of normal mice. J Immunol 1996;156(12):4783-8.

[10] Reeves G. C-reactive protein. Aust Prescr 2007;30(3):74-6.

[11] Foulon W, Van Liedekerke D, Demanet C, et al. Markers of infection and their relationship to preterm delivery. Am J Perinatol 1995;12(3):208-11. 
[12] Hvilsom GB, Thorsen P, Jeune B, et al. C-reactive protein: a serological marker for preterm delivery? Acta Obstetricia Gynecologica Scandinavica 2002;81(5):424-9.

[13] Reron A, Huras H, Szymik M, et al. C-reactive protein as a predictor of threatening preterm delivery. Neuro Endocrinol Lett 2004;25(4):302-6.

[14] Pitiphat W, Gillman MW, Joshipura KJ, et al. Plasma Creactive protein in early pregnancy and preterm delivery. American Journal Epidemiology 2005;162(11):1108-13.

[15] Lohsoonthorn V, Qiu C, Williams MA. Maternal serum $\mathrm{C}$-reactive protein concentrations in early pregnancy and subsequent risk of preterm delivery. Clinical Biochemistry 2007;40(5-6):330-5.

[16] Grgic G, Skokic F, Bogdanovic G. C-reactive protein as a biochemical marker of idiopathic preterm delivery. Med Arh 2010;64(3):132-4.

[17] Riboni F, Vitulo A, Plebani M, et al. Combination of biochemical markers in predicting pre-term delivery. Archives Gynecology Obstetrics 2012;285(1):61-6.

[18] Kulshreshtha S, Anjum S, Agrawal A, et al. Patterns of plasma C-reactive protein levels in early pregnancy and consequent risks of preterm delivery. Journal of Evolution of Medical and Dental Sciences 2015;4(65):11335-41.

[19] Mirzaie_F, Mohammah-Alizadeh_S. Contributing factors of preterm delivery in parturient in a university hospital in Iran. Saudi_Med_J 2007;28(3):400-4.

[20] Al-Jasmi F, Al-Mansoor F, Alsheiba A, et al. Effect of interpregnancy interval on risk of spontaneous preterm birth in Emirati women, United Arab Emirates. Bull World Health Organ 2002;80(11):8715.
[21] Brown JS, Adera_T, Masho_SW. Previous abortion and the risk of low birth weight and preterm births. J Epidemiol_Community_Health 2008;62(1):16-22.

[22] Lo CC, Hsu JJ, Hsieh CC, et al. Risk factors for spontaneous preterm delivery before 34 weeks of gestation among Tiawanese women. Tiawan J Obstet Gynecol 2007;46(4):389-94.

[23] Freak-Poli_R, Chan_A, Tucker_G, et al. Previous abortion and risk of preterm birth: a population study. J_Matern Fetal_Neonatal_Med 2009;22(1):1-7.

[24] Smith GC, Shah I, White IR, et al. Maternal and biochemical predictors of spontaneous preterm birth among nulliparous women: a systematic analysis in relation to the degree of prematurity. International Journal of Epidemiology 2006;35(5):1169-77.

[25] Smith GCS, Pell JP, Dobbie R. Interpregnancy interval and risk of preterm birth and neonatal death: retrospective cohort study. British Medical Journal 2003;327(7419):851.

[26] Dafopoulos KC, Galazios GC, Tsikouras PN, et al. Interpregnancy interval and the risk of preterm birth in Thrace, Greece. European Journal of Obstetrics and Gynecology Reproductive Biology 2002;103(1):14-7.

[27] Sunagawa S, Takagi K, Ono K, et al. Comparison of biochemical markers and cervical length for predicting preterm delivery. Journal Obstetrics Gynaecology Research 2008;34(5):812-9.

[28] Mazor M, Kassis A, Horowitz S, et al. Relationship between $\mathrm{C}$-reactive protein levels and intra-amniotic infection in women with preterm labor. Journal of Reproductive Medicine 1993;38(10):799-803. 